Brit. F. vener. Dis. (1967), 43, 133.

\title{
ORAL CHLORAMPHENICOL ALONE AND WITH INTRAMUSCULAR PROCAINE PENICILLIN IN THE TREATMENT OF GONORRHOEA*
}

\author{
BY \\ H. C. GJESSING AND K. ÖDEGAARD \\ From the Bureau of Public Health, Department of Venereal Diseases, \\ and the National Institute of Public Health, Department of Bacteriology, Oslo, Norway
}

The present paper has two main subjects; the study of the efficacy of one intramuscular injection of procaine penicillin combined with oral administration of $1 \mathrm{~g}$. chloramphenicol (Schedule 1) and the efficacy of $1 \mathrm{~g}$. chloramphenicol alone in a single oral dose (Schedule 2).

In a previous paper (Gjessing and Ödegaard, 1966), we gave the results of one intramuscular injection of 600,000 units procaine penicillin, combined with the oral administration of $0.5-0.75 \mathrm{~g}$. chloramphenicol in 500 male patients suffering from gonorrhoea. The failure rate was 3 per cent. in all patients treated, but when the group infected with gonococci less sensitive to penicillin (minimum inhibitory concentration $0 \cdot 125-2$ units $/ \mathrm{ml}$.) was taken separately, the failure rate was $5 \cdot 1$ per cent. The result was considered satisfactory. However, hoping to improve the issue and having seen no complications, we decided to raise the dose of chloramphenicol to $1 \mathrm{~g}$., but to continue with the same dosage of penicillin. The results are shown in Table $I$.

Studying the earlier literature on the efficacy of chloramphenicol, it might be supposed that the decisive factor in the combined treatment is the chloramphenicol and that the outcome would be the same even if penicillin were excluded.

Willcox (1962) reviewed the work of some authors who had had considerable success with chloramphenicol. Greaves, MacDonald, Romansky, and Taggart (1950) treated 75 patients with single oral doses of $0.75 \mathrm{~g}$. chloramphenicol and obtained a cure rate of 96 per cent. Butler, Brewer, Condit, and Johnston (1952) had complete success with single oral doses of $3 \mathrm{~g}$. A 92 per cent. success rate was achieved with single doses of $2 \mathrm{~g}$. as well as with $1 \mathrm{~g}$. by Barrett and Burton (1953). Robinson and Wells (1952), using single injections

\footnotetext{
* Received for publication October 21, 1966.
}

of 1 g. chloramphenicol, obtained a cure rate of 86 per cent.

Chloramphenicol was to some extent discredited when it became known that it might be accompanied by changes in the bone marrow and by aplastic anaemia. However, it seems that complications are generally due to large doses and/or prolonged treatment.

For psychological and epidemiological reasons we have hitherto been opposed to exclusively oral administration of drugs as routine treatment of gonorrhoea. But these objections are not so serious if the tablets are swallowed under supervision. At all events, from a scientific point of view, we saw no harm in giving a limited number of patients a relatively small oral dose of chloramphenicol.

We have therefore treated 200 male patients with an oral dose of $1 \mathrm{~g}$. chloramphenicol.

\section{Material and Methods}

The subjects of the trial were 700 consecutive male patients in whom gonococci were demonstrated by direct microscopical examination and by cultureDecember, 1964, to July, 1966.

Treatment The first 500 patients were given one intramuscular injection of 600,000 units benzyl procaine penicillin and at the same time a single oral dose of 1 g. chloramphenicol (four tablets, each of $0.25 \mathrm{~g}$.) swallowed under supervision. The remaining 200 cases received only the oral dose of $1 \mathrm{~g}$. chloramphenicol.

The methods of diagnosis, sensitivity tests, follow-up and distinction between relapse and re-infection were mainly the same as described in previous papers, (Gjessing, 1959; Gjessing and Odegaard, 1962a, b).

Culture and Sensitivity Tests The specimens were brought to the laboratory on charcoal-impregnated swabs placed in solid Stuart transport medium (Ringertz, 1960). The diagnostic criteria for a positive culture were: typical oxydase-positive colonies consisting of Gram-negative diplococci on chocolate agar, acid formation from dextrose, but not from maltose and sucrose, and no growth on nutrient agar. To determine 
the sensitivity to penicillin, a plate-dilution method was used. Two-fold dilutions of crystalline penicillin G were used to give a range of penicillin concentrations in chocolate agar medium from 0.0075 to 2 units $/ \mathrm{ml}$. The technique is the same as that previously employed by Odegaard (1960). The sensitivity of the gonococci was registered as the minimum concentration at which no growth could be observed with the naked eye. As to the dilution test method, we have used the expression decreased sensitivity where the inhibitory concentration was 0.125 units $/ \mathrm{ml}$. or more. A paper disk method (Ericsson, Högman, and Wickman, 1954) was employed to determine the sensitivity of the gonococci to streptomycin, chloramphenicol, tetracycline, erythromycin, and sulphonamide. The chloramphenicol disks contained $30 \mu \mathrm{gm}$. each.

With the intention of obtaining a more graduated or accurate determination of the sensitivity to chloramphenicol, a plate-dilution method was used in addition to the paper disk method in 200 cases treated exclusively with this antibiotic. Two-fold dilutions of chloramphenicol were used in chocolate agar medium giving a range from 0.25 to $4 \mu \mathrm{g}$. $/ \mathrm{ml}$. The technique was the same as that employed in the penicillin sensitivity test.

Follow-up Patients were if possible re-examined once a week for a month. Besides direct microscopy, specimens for culture were taken on re-examination in all cases in which the infection was due to gonococci with decreased sensitivity to penicillin and in patients with more or less pronounced symptoms of posttreatment urethritis. However, in the latter part of the trial, specimens for culture were taken from all patients on re-examination regardless of the first sensitivity test. In males, two negative findings, 7 and 14 days after treatment, are probably sufficient to declare the patient cured.

Distinction between Relapse and Re-infection The distinction is based on the theory that relapse generally occurs within 1 or 2 weeks after treatment. Suspicion of re-infection increases with the length of the gonococcus-free interval between the completion of treatment and the new demonstration of gonococci. When the patient admits sexual intercourse during the follow-up period and the symptoms appear at the appropriate time, re-infection is indicated. By means of changes in the sensitivity pattern of strains isolated, it seems possible in some cases to decide the question with further certainty (Gjessing and Ödegaard, 1962a).

\section{Results}

The sensitivity of the gonococci to penicillin determined by the plate-dilution method showed a minimum inhibitory concentration varying between $<0.015$ and 2 units $/ \mathrm{ml}$. (Table I, and Takle II, opposite). All the 700 strains were sensitive to chloramphenicol when examined with the paper disk method. In the 200 strains examined by the plate-dilution method the minimum inhibitory
TABLE I

SENSITIVITY OF GONOCOCCI TO PENICILLIN

Relation between sensitivity and treatment failure in 500 male patients, each treated with 600,000 units procaine penicillin and a single oral dose of $1 \mathrm{~g}$. chloramphenicol

\begin{tabular}{|c|c|c|c|c|c|}
\hline \multirow{3}{*}{$\begin{array}{l}\text { Minimum } \\
\text { Inhibitory } \\
\text { Concen- } \\
\text { tration of } \\
\text { Penicillin } \\
\text { (units } / \mathrm{ml} \text {.) }\end{array}$} & \multirow{3}{*}{$\begin{array}{c}\text { No. } \\
\text { of } \\
\text { Patients }\end{array}$} & \multirow{3}{*}{$\begin{array}{c}\text { Not } \\
\text { Followed } \\
\text { up }\end{array}$} & \multicolumn{3}{|c|}{ Followed-up } \\
\hline & & & \multicolumn{2}{|c|}{ Gc. Positive } & \multirow{2}{*}{$\begin{array}{c}\text { Gc. } \\
\text { Negative }\end{array}$} \\
\hline & & & Relapses & $\begin{array}{c}\mathrm{Re}- \\
\text { infections }\end{array}$ & \\
\hline $\begin{array}{l}2 . \\
1 \cdot \\
0 \cdot 5 \\
0 \cdot 25 \\
0 \cdot 125 \\
0.06 \\
0.03 \\
₹ 0.015\end{array}$ & $\begin{array}{r}6 \\
28 \\
64 \\
87 \\
33 \\
32 \\
158 \\
92\end{array}$ & $\begin{array}{r}1 \\
4 \\
12 \\
27 \\
14 \\
7 \\
50 \\
23\end{array}$ & $\begin{array}{l}3 \\
2 \\
3 \\
1\end{array}$ & $\begin{array}{l}1 \\
4 \\
5 \\
2 \\
2 \\
6 \\
7\end{array}$ & $\begin{array}{r}22 \\
21 \\
45 \\
55 \\
16 \\
23 \\
102 \\
62\end{array}$ \\
\hline Total & 500 & 138 & 9 & 27 & 326 \\
\hline
\end{tabular}

concentration of chloramphenicol varied between 0.25 and $4 \mu \mathrm{g} . / \mathrm{ml}$. (Table III).

TABLE III

SENSITIVITY OF GONOCOCCI TO CHLORAMPHENICOL (PLATE-DILUTION METHOD)

Relation between degree of sensitivity and relapse in 200 male patients, each treated with a single oral dose of $1 \mathrm{~g}$. chloramphenicol

\begin{tabular}{c|c|c}
\hline $\begin{array}{c}\text { Minim.um Inhibitory } \\
\text { Concentration of } \\
\begin{array}{c}\text { Chloramphenicol } \\
(\mu \mathrm{g} . / \mathrm{ml} .)\end{array}\end{array}$ & $\begin{array}{c}\text { No. of } \\
\text { Patients }\end{array}$ & Relapses \\
\hline 4.0 & 2 & 2 \\
1.0 & 9 & 2 \\
0.5 & 135 & 11 \\
0.25 & 54 & 2 \\
\hline Total & 200 & 17 \\
& & $(8.5$ per cent. $)$ \\
\hline
\end{tabular}

The sensitivity of the gonococci to penicillin and to chloramphenicol determined by the plate-dilution method is juxtaposed in Table II. Sensitivity to antibiotics other than penicillin and chloramphenicol will not be discussed in the present paper because they are not connected with the treatment in question.

Schedule 1 In 500 patients who received one intramuscular injection of procaine penicillin 600,000 units combined with an oral dose of chloramphenicol $1 \mathrm{~g}$., there were nine failures ( 1.8 per cent.). All these cases of relapse were seen among 218 patients infected with gonococci with decreased sensitivity to penicillin. The failure rate in this group taken separately is consequently 4 per cent. (Table I).

Schedule 2 In 200 patients treated with a single oral dose of $1 \mathrm{~g}$. chloramphenicol only, there were seventeen failures $(8.5$ per cent.). Fifteen of these occurred among patients infected with gonococci where the minimum inhibitory 
TABLE II

SENSITIVITY OF GONOCOCCI TO PENICILLIN AND CHLORAMPHENICOL*

(PLATE-DILUTION METHOD)

Relation between sensitivity and result of treatment of 200 male patients each treated with a single oral dose of $1 \mathrm{~g}$. chloramphenicol

\begin{tabular}{|c|c|c|c|c|c|c|}
\hline \multirow{2}{*}{\multicolumn{2}{|c|}{$\begin{array}{l}\text { Minimum } \\
\text { Inhibitory Concentration }\end{array}$}} & \multirow{3}{*}{$\begin{array}{l}\text { No. of } \\
\text { Patients }\end{array}$} & \multirow{3}{*}{$\begin{array}{l}\text { Not } \\
\text { Followed-up }\end{array}$} & \multicolumn{3}{|c|}{ Followed-up } \\
\hline \multirow{2}{*}{$\begin{array}{l}\text { Penicillin } \\
\text { (units/ml.) }\end{array}$} & & & & \multicolumn{2}{|c|}{ Gc. Positive } & \multirow{2}{*}{ Gc. Negative } \\
\hline & $\begin{array}{l}\text { Chloramphenicol } \\
(\mu \mathrm{g} . / \mathrm{ml} .)\end{array}$ & & & Relapses & Re-infections & \\
\hline $1 \cdot 0$ & $\begin{array}{l}0.5 \\
1 \cdot 0 \\
4 \cdot 0\end{array}$ & $\begin{array}{l}1 \\
3 \\
2\end{array}$ & 1 & 2 & & 1 \\
\hline 0.5 & $\begin{array}{l}0 \cdot 25 \\
0.5 \\
1 \cdot 0\end{array}$ & $\begin{array}{r}2 \\
22 \\
1\end{array}$ & 4 & 3 & & $\begin{array}{r}2 \\
15 \\
1\end{array}$ \\
\hline $0 \cdot 25$ & $\begin{array}{l}0 \cdot 25 \\
0 \cdot 5 \\
1 \cdot 0\end{array}$ & $\begin{array}{r}1 \\
17 \\
2\end{array}$ & 6 & 3 & & $\begin{array}{l}1 \\
8 \\
2\end{array}$ \\
\hline $0 \cdot 125$ & $\begin{array}{l}0 \cdot 25 \\
0 \cdot 5\end{array}$ & $\begin{array}{r}2 \\
15\end{array}$ & $\begin{array}{l}2 \\
5\end{array}$ & 1 & & 9 \\
\hline 0.06 & $\begin{array}{l}0.25 \\
0.5 \\
1.0\end{array}$ & $\begin{array}{r}9 \\
11 \\
1\end{array}$ & $\begin{array}{l}1 \\
4\end{array}$ & 1 & & $\begin{array}{l}8 \\
6 \\
1\end{array}$ \\
\hline 0.03 & $\begin{array}{l}0.25 \\
0.5 \\
1.0\end{array}$ & $\begin{array}{r}24 \\
52 \\
1\end{array}$ & $\begin{array}{r}5 \\
14\end{array}$ & 2 & 2 & $\begin{array}{r}15 \\
35 \\
1\end{array}$ \\
\hline $\bar{\Sigma} 0.015$ & $\begin{array}{l}0.25 \\
0.5 \\
1 \cdot 0\end{array}$ & $\begin{array}{r}16 \\
17 \\
1\end{array}$ & $\begin{array}{l}3 \\
3\end{array}$ & 3 & 2 & $\begin{array}{r}11 \\
11 \\
1\end{array}$ \\
\hline \multicolumn{2}{|l|}{ Total } & 200 & 48 & 17 & 7 & 128 \\
\hline
\end{tabular}

* Dilutions which do not correspond to any strains examined are omitted from the Table.

concentration of chloramphenicol varied between 0.5 and $4 \mu \mathrm{g} . / \mathrm{ml}$. Only two cases of relapse were observed in cases in which the minimum inhibitory concentration was $0.125 \mu \mathrm{g} . / \mathrm{ml}$. (Table III).

\section{Treatment of Relapse}

The nine patients who relapsed amongst the 500 treated with penicillin and chloramphenicol combined were re-treated as follows:

Seven were given ampicillin $(0.5 \mathrm{~g}$. four times a day at 4-hrly intervals for 6 days-in all $12 \mathrm{~g}$. ampicillin); six of these were cured and one was not reexamined. One with relapse (?) was treated with the same dose of penicillin and chloramphenicol and was cured. The last received oxytetracycline $0.25 \mathrm{~g} . \times 16$ because he was at first believed to be suffering from a non-gonococcal urethritis. The result was a second relapse. He did not return for further treatment.

The seventeen patients who relapsed amongst the 200 treated with a single oral dose of $1 \mathrm{~g}$. chloramphenicol only were re-treated as follows:

Two were re-treated with the dosage of ampicillin detailed above; one was cured, and the other not followed up. One patient was treated elsewhere. The remaining fourteen were given one intramuscular injection of 600,000 units procaine penicillin together with a single oral dose of $1 \mathrm{~g}$. chloramphenicol. Of these ten were cured, two not followed up, and two had a second relapse. The two patients with a second relapse were given ampicillin (12 g.); one was cured and the other, a seaman, could not be followed up.

\section{Discussion}

Even if the number of patients treated with chloramphenicol alone is relatively small, it is obvious that this method is inferior to the combined treatment used, and the difference is significant at the 0.1 per cent. level. Knowing that one intramuscular injection of 600,000 units procaine penicillin has a considerable failure rate if the infection is due to gonococci with decreased sensitivity to penicillin, this could lead one to believe that there may be a synergic influence between the two antibiotics.

However, combinations of antibiotics can have one of three different effects: additive, synergic, or antagonistic (Garrod, 1964). In accordance with the law formulated by Jawetz and Gunnison (1952), it is generally agreed that synergy is rarely seen except in the action of a pair of bactericidal drugs, and that antagonism results only from combining a bactericidal with a bacteriostatic drug. Because penicillin is bactericidal and chloramphenicol bacteriostatic, there was the possibility that a combination of both could be antagonistic in their 
effect on gonococci. We have tried to examine the combined action of the two drugs in vitro on gonococcal cultures isolated from ten patients using a diffusion method with paper strips impregnated with penicillin and with chloramphenicol placed at right angles on chocolate agar plates. We found no antagonistic bacteriostatic influence, and as expected (Jawetz's law) no synergic influence either.

The explanation of the efficacy of the combined treatment in question is probably this: penicillin will eradicate almost all gonococci which are sensitive to penicillin, but only a certain percentage of strains which have a reduced sensitivity to this antibiotic. Many of the gonococcal strains which penicillin cannot eradicate, will then be eliminated by chloramphenicol.

\section{Summary}

The sensitivity of the gonococci to different drugs was tested in cultures from 700 male patients. The sensitivity to penicillin $G$ was in all cases determined by a plate-dilution method. The sensitivity to chloramphenicol was ascertained by a paper disk method in all cases, but in addition a plate-dilution method was employed in the last 200 cultures.

The minimum inhibitory concentration of penicillin varied from $<0.015$ to 2 units $/ \mathrm{ml}$. All strains were sensitive to chloramphenicol according to the paper disk method.

In the last 200 cases in which the plate-dilution method was employed in addition, the sensitivity to chloramphenicol varied between 0.25 and $4 \mu \mathrm{g} . / \mathrm{ml}$.

500 male patients received one intramuscular injection of 600,000 units procaine penicillin and at the same time a single oral dose of $1 \mathrm{~g}$. chloramphenicol (Schedule 1); there were nine failures ( 1.8 per cent.).

200 male patients were given only a single oral dose of $1 \mathrm{~g}$. chloramphenicol (Schedule 2); there were seventeen relapses $(8.5$ per cent.).

It is concluded that the efficacy of the combined treatment in question is far better than that of the same doses of the two drugs given separately. The result of treatment seen in relation to the sensitivity determined by the plate-dilution method (Schedule 2) may indicate a distinction between gonococci very sensitive and less sensitive to chloramphenicol.

\section{REFERENCES}

Barrett, C. D., and Burton M. E. (1953). Amer. F. Syph. 17, 165.

Butler, P. G., Brewer, A. F., Condit, P. K., and Johnston, J. (1952). Ibid., 36, 269.

Ericsson, H., Högman, C., and Wickman, K. (1954). Scand. F. clin. Lab. Invest., 6, Suppl. 11, p. 21.

Garrod, L. P. (1964). In "IIIrd International Congress of Chemotherapy, 1963, Stuttgart-Proceedings", vol. 1, p. 234. Thieme, Stuttgart.

Gjessing, H. C. (1959). Brit. F. vener. Dis., 35, 256.

and Ödegaard, K. (1962a). Ibid., 38, 26.

- (1962b). Acta derm.-venereol. (Stockh.), 42, 305.

- (1966). Brit. F. vener. Dis., 42, 107.

Greaves, A. B., MacDonald, G. R., Romansky, M. J., and Taggart, S. R. (1950). F. vener. Dis. Inform., 31, 261 .

Jawetz, E., and Gunnison, J. B. (1952). Antibiot. Chemother., 2, 243.

Ödegaard, K. (1960). Acta derm.-venereol. (Stockh.), 40, 504 .

Ringertz, O. (1960). Acta path. microbiol. scand., 48, 105.

Robinson, R. C. V., and Wells, T. L. (1952). Amer. $\mathcal{F}$. Syph., 36, 264.

Willcox, R. R. (1962). Acta derm.-venereol. (Stockh.), 42, 484 .

L'administration par voie buccale du Chloramphenicol seul et en combinaison

avec la procaine pénicilline par voie musculaire dans le traitement de la blennorragie

\section{RÉSUMÉ}

La sensibilité en cultures des gonocoques provenant de 700 patients a été testée avec des médicaments différents. La sensibilité à la pénicilline $\mathrm{G}$ a été dans chaque cas determinée par la méthode de dilution sur plaques. La sensibilité au Chloramphenicol a été étudiée par la méthode "paper disk" dans chaque cas, mais de plus par la méthode de dilution sur plaques dans les 200 dernières cultures.

La concentration inhibitrice minimum de la pénicilline a varié de 0,015 à 2 unités $/ \mathrm{ml}$. Toutes les souches sont sensibles au Chloramphenicol d'après la méthode "paper disk".

Dans les 200 derniers cas ou la méthode de dilution sur plaques a été employée par surcroît, la sensibilité au Chloramphenicol a varié de 0,25 à $4 \mu \mathrm{g} . / \mathrm{ml}$.

500 malades avaient reçu une injection de 600,000 unités par voie intramusculaire et en même temps une seule dose par voie buccale d'un gramme de Chloramphenicol (Schedule 1); on a compté neuf échecs $(1,8$ pour cent).

200 patients avaient reçu une seule dose d'un gramme de Chloramphenicol (Schedule 2); on a compté 17 rechutes ( 8,5 pour cent).

On conclut que l'éfficacité du traitement combiné en question est supérieure à celle de ces mêmes médicaments donnés séparement et à la même dose. Le résultat du traitement vu en relation de la sensibilité déterminée par la méthode de dilution sur plaques (Schedule 2) peut indiquer une distinction entre les gonocoques qui sont très sensibles ou moins sensibles au Chloramphenicol. 